\title{
Orostachys japonicus DW and EtOH Extracts Induce Apoptosis in Cholangiocarcinoma Cell Line SNU-1079
}

\author{
Eun Sol Choi, Jang Hoon Lee \\ Department of Clinical Korean Medicine, Graduate School, Kyung Hee University
}

\begin{abstract}
Objectives: This study was performed to investigate the anti-tumor effect of $O$. japonicus extracts on intrahepatic cholangiocarcinoma cell line SNU-1079.

Methods: Cholangiocarcinoma SNU-1079 cells were treated with various concentrations of $O$. japonicus DW and EtOH extracts $(0-300 \mu \mathrm{g} / \mathrm{ml})$ for 24,48 or $72 \mathrm{~h}$. Cell viability was evaluated through a PMS/MTS assay, and the apoptosis rate was examined through ELISA assay and flow cytometry analysis. The mRNA expression of apoptosisand cell cycle progression-related genes (Bcl-2, Mcl-1, Bax, Survivin, Cyclin D1, and p21) was evaluated using real-time PCR, and the caspase activity was examined using immunoblot analysis.

Results: $O$. japonicus extracts inhibited cell proliferation and increased apoptosis rate in both ELISA assay and flow cytometry analysis. O. japonicus extracts decreased Bcl-2, Mcl-1, Survivin, and Cyclin D1 mRNA expression and increased Bax mRNA level. O. japonicus extracts also increased Caspase-3 activation. Overall, O. japonicus DW extracts were more effective than EtOH extracts.

Conclusions: O. japonicus inhibited cell proliferation and induced apoptosis in SNU-1079 cells via mitochondria -mediated intrinsic pathway, which leads to Caspase-3 activation. The results indicate that $O$. japonicus is a potential therapeutic herb with anti-tumor effect against intrahepatic cholangiocarcinoma.
\end{abstract}

\section{$\overline{\text { Key Words }}$ : Orostachys japonicus, Intrahepatic cholangiocarcinoma, SNU-1079, Apoptosis, Anti-tumor effect, Caspase-3}

\section{Introduction}

Cholangiocarcinoma (CCA) defines as bile duct cancer occurring in the intrahepatic, perihilar, or distal biliary tree, excluding gallbladder or ampulla of Vater. Hepatobiliary malignancies account for $13 \%$ of cancer-related deaths globally, and $10 \%-20 \%$ of these are attributable to $\mathrm{CCA}^{1,2}$. Although CCA is the most common biliary malignancy and the second most common hepatic malignancy, it shows poor prognosis due to the lack of specific symptoms and high invasiveness which often cannot be curable by surgical treatments ${ }^{3,4}$. Moreover, CCA cells do not respond or weakly respond to chemotherapy or radiotherapy ${ }^{5}$, thus researches for therapeutic herbal medicines are required. Particularly, investigation of therapeutic herbs for intrahepatic cholangiocarcinoma (iCCA) is earnestly needed since epidemiologic studies have indicated that the age-adjusted mortality rate of iCCA is increasing, whereas the mortality rate of perihilar CCA and distal CCA could be decreasing ${ }^{2,6-10}$.

\footnotetext{
- Received : 16 November $2015 \quad$ - Revised : 13 December $2015 \quad$ Accepted : 24 December 2015

- Correspondence to : Jang Hoon Lee

Department of Clinical Korean Medicine, Graduate School, Kyung Hee University

\# Internal medicine department I, Kyung Hee University Korean Medicine Hospital, 23, Kyung-Hee-dae-ro, Dongdaemun-gu, Seoul 130-872, Republic of Korea

Tel : +82-2-958-9118, Fax : +82-2-958-9258, E-mail : komclive@khmc.or.kr
} 
CCA develops from the accumulation of genetic and epigenetic alterations in regulatory genes in cholangiocytes $^{11-13}$. To prove the anti-tumor effect of a herbal medicine, investigation of apoptosis mechanism has been considered as valid method, since defects in apoptotic pathways are believed to contribute to malignancy formation ${ }^{14,15}$. Apoptosis is essential mechanism for normal development, host defense, and suppression of oncogenesis, and it can be explained as a programmed cell death involving the degradation of cellular components by cysteine proteases called caspases ${ }^{16,17}$. These caspases can be activated through either the mitochondria-mediated intrinsic pathway or death receptor-mediated extrinsic pathway. Investigation of molecular mechanism of apoptosis seems necessary, as activation of these pathways is a key mechanism of anti-tumor agents to kill tumor cells ${ }^{18,19}$.

Orostachys japonicus (O. japonicus) extracts have shown various biological activities including anti-inflammatory ${ }^{20}$, neuroprotective ${ }^{21}$, anti-ulcerative ${ }^{22}$, anti-oxidant $^{23}$, and anti-tumor effects ${ }^{24-26}$. Particularly, it has been recognized as a potential anti-tumor treatment for a variety of tumor cells in Korea. In the previous studies, the extract of $O$. japonicus showed anti-tumor effect via inhibition of cell proliferation and induction of apoptosis in human hepatic stellate cells ${ }^{27}$, leukemia cells ${ }^{28,29}$, human colon cancer cells ${ }^{30}$, and human prostate cancer cells ${ }^{31}$.

In spite of the therapeutic suggestion of $O$. japonicus, the anti-tumor effect against CCA has not been studied yet. Considering the increasing mortality rate, iCCA cell line was utilized as a subject of our investigation. SNU-1079 is human biliary tract cancer cell line from intrahepatic duct ${ }^{32}$, which has been used to investigate the anti-tumor effect of Korean herbal medicines ${ }^{33,34}$. Thereby it was regarded as an appropriate model to investigate the anti-tumor effect of $O$. japonicus against iCCA.

In the present study, O. japonicus DW and EtOH extracts were treated to SNU-1079 cell line to investigate the capability as an anti-tumor agent against CCA. We measured the inhibitory effect on cell proliferation and regulatory effect on apoptosis -related genes and caspase activation to demonstrate by which molecular pathway $O$. japonicus functions to induce apoptosis.

\section{Materials and Methods}

\section{Preparation of Orostachys japonicus $A$. Berger extract (DW \& EtOH)}

After purchased from Kyung Hee Korean Herbal Medicine Research Center, Seoul, Korea, $O$. japonicus was cut down in a proper size and used for extraction procedure.

$D W$ extract $100 \mathrm{~g}$ of $O$. japonicus and $1000 \mathrm{ml}$ Distilled Water were boiled for 2 hours using extractor. The resulting water extract was filtered through a Whatmann Paper, and then vacuum evaporation was proceded by rotary evaporator. After the concentrated extract was freeze-dried (EYELA, Tokyo, Japan), the final weight of the extract was $12.8 \mathrm{~g}$, which was $12.8 \%$ of natural product.

EtOH extract $100 \mathrm{~g}$ of $O$. japonicus and $1000 \mathrm{ml}$ $50 \%$ EtOH were boiled for 2 hours using extractor. The resulting ethanol extract was filtered through a Whatmann Paper, and then vacuum evaporation was proceded by rotary evaporator. After the concentrated extract was freeze-dried (EYELA, Tokyo, Japan), the final weight of the extract was $6.5 \mathrm{~g}$, which was $6.5 \%$ of natural product.

\section{Cell culture}

The human cholangiocarcinoma cell line SNU -1079 was purchased from the Korean Cell Line Bank (Seoul, Korea). The cells were cultured in RPMI 1640 (Gibco, Grand Island, NY, USA) containing $10 \%$ fetal bovine serum (FBS), 100 
$\mathrm{U} / \mathrm{ml}$ penicillin and $100 \mu \mathrm{g} / \mathrm{ml}$ streptomycin at $37^{\circ} \mathrm{C}$ in a humidified atmosphere of $5 \% \mathrm{CO}_{2}$ and $95 \%$ air.

\section{Cell viability assay}

Cell proliferation was evaluated using the CellTiter 96 Aqueous One solution (Promega, Madison, WI, USA). SNU-1079 cells were seeded at a density of $1 \times 10^{4}$ cells/well in 96-well plate and incubated with various concentrations of $O$. japonicus DW and EtOH extracts (0, 50, 100, 200 and $300 / \mathrm{ml}$ ) at $37^{\circ} \mathrm{C}$ for 24,48 or $72 \mathrm{~h}$. Cell viability was determined through a colorimetric assay by using PMS/MTS solution. The absorbance was determined at $492 \mathrm{~nm}$ with background subtraction at $650 \mathrm{~nm}$.

\section{ELISA assay}

The number of apoptotic SNU-1079 cells was measured using the Cell Death Detection ELISA ${ }^{\text {plus }}$ kit (Roche Molecular Biochemicals, Manndeim, Germany). Cells $\left(1 \times 10^{4}\right)$ were incubated with various concentrations of $O$. japonicus DW and EtOH extracts $(0,100,200$ and 300) for 24, 48 or $72 \mathrm{~h}$. They were then lysed with the cell lysis buffer $(200 \mu 1)$. The cell lysates were assayed for DNA fragments by using the cell death ELISA $^{\text {plus }}$ according to the manufacturer's protocol. DNA fragmentation was evaluated at $405 \mathrm{~nm}$ against an untreated control.

\section{FACS analysis}

Cells $\left(5 \times 10^{5}\right)$ were treated with various concentrations of $O$. japonicus DW and $\mathrm{EtOH}$ extracts $(0,150$ and 300$)$ for 24,48 or $72 \mathrm{~h}$. At the end of the treatment period, the cells were harvested and washed with PBS. They were then fixed with $70 \%$ ethanol for $1 \mathrm{~h}$, treated with RNase A $(20 \mu \mathrm{g} / \mathrm{m} \ell)$ at $37{ }^{\circ} \mathrm{C}$ for $1 \mathrm{~h}$ and stained with Annexin-V/PI assay kit (BD Biosciences, USA).
The apoptosis rate was analyzed using a FACSCalibur flow cytometer and CellQuest software (Becton Dickinson, Franklin Lakes, NJ, USA).

\section{RNA extraction and real-time PCR}

Total RNA was purified from cultured cells by using an RNA-Bee solution kit following the manufacturer's protocol (Tel-Test, Friendswood, TX, USA). First-strand cDNA synthesis was performed with $1 \mu \mathrm{g}$ of total RNA and transcribed into cDNA using a reverse transcription system with random hexamers according to the manufacturer's protocol. The primer sequences used were as follows (Table 1):

Table 1. Primer Sequences for Real-Time PCR

\begin{tabular}{|c|c|c|}
\hline Gene & Primer sequence & Size \\
\hline$B c l-2$ & $\begin{array}{l}\text { 5'-GATTGATGGGATCGTTGCCTTA-3' } \\
\text { 5'-CCTTGGCATGAGATGCAGGA-3' }\end{array}$ & $200 \mathrm{bp}$ \\
\hline Mcl-1 & $\begin{array}{l}\text { 5'-CTCATTTCTTTTGGTGCCTTT-3' } \\
\text { 5'-CCAGTCCCGTTTTGTCCTTAC-3' }\end{array}$ & $117 \mathrm{bp}$ \\
\hline $\operatorname{Bax}$ & $\begin{array}{l}\text { 5'-GGATGCGTCCACCAAGAAG-3', } \\
\text { 5'-GCCTTGAGCACCAGTTTGC-3' }\end{array}$ & $216 \mathrm{bp}$ \\
\hline Survivin & $\begin{array}{l}\text { 5'-GGCCCAGTGTTTCTTCTGCTT-3' } \\
\text { 5'-GCAACCGGACGAATGCTTT-3' }\end{array}$ & $91 \mathrm{bp}$ \\
\hline $\begin{array}{l}\text { Cyclin } \\
\text { D1 }\end{array}$ & $\begin{array}{l}\text { 5'-CCGTCCATGCGGAAGATC-3' } \\
\text { 5'-ATGGCCAGCGGGAAGAC-3' }\end{array}$ & 86 bp \\
\hline$p 21$ & $\begin{array}{l}\text { 5'-CAGACCAGCATGACAGATTTC-3' } \\
\text { 5'-TTAGGGCTTCCTCTTGGAGA-3' }\end{array}$ & $66 \mathrm{bp}$ \\
\hline$\beta$-actin & $\begin{array}{l}\text { 5'-GCGAGAAGATGACCCAGATC-3' } \\
\text { 5'-GATAGCACAGCCTGGATAG-3' }\end{array}$ & 77 bp \\
\hline
\end{tabular}

Real-time PCR was performed using a StepOneplus real-time PCR system with the Power SYBR Green PCR Master Mix (Applied Biosystems, Foster, CA, USA). The PCRs were performed with $1 \mathrm{ml}$ of cDNA in $20 \mathrm{ml}$ reaction mixtures which is consisted of $10 \mathrm{ml}$ Power SYBR Green PCR Master Mix, $2 \mathrm{ml}$ of primers, and $7 \mathrm{ml}$ of PCR-grade water. The reactions were performed with a denaturation step at $95{ }^{\circ} \mathrm{C}$ for $10 \mathrm{~min}$, followed by 40 cycles at $95{ }^{\circ} \mathrm{C}$ for $15 \mathrm{~s}$ and at $60{ }^{\circ} \mathrm{C}$ for $1 \mathrm{~min}$. 
The crossing point of each target gene with $\beta$-actin was calculated by using the formula $2^{\text {-(target gene - }}$ B-actin) and the relative amounts of the PCR products were quantified.

\section{Immunoblot analysis}

Cells were collected and washed with cold PBS then lysed using lysis buffer $[20 \mathrm{mM}$ Tris- $\mathrm{HCl}(\mathrm{pH}$ 7.5), $150 \mathrm{mM} \mathrm{NaCl}, 1 \mathrm{mM} \mathrm{Na} 2$ EDTA, $1 \mathrm{mM}$ EGTA, $1 \%$ Triton, $2.5 \mathrm{mM}$ sodium pyrophosphate, $1 \mathrm{mM} \beta$-glycerophosphate, $1 \mathrm{mM} \mathrm{Na} \mathrm{VO}_{4}$, and 1 $\mu \mathrm{g} / \mathrm{ml}$ leupeptin] containing $1 \mathrm{mM}$ PMSF (Cell Signaling Technology, Inc., Boston, MA, USA). The protein concentration was determined by a BCA protein assay according to the manufacturer's protocol. Thirty micrograms of protein were fractionated by $12 \%$ SDS-PAGE and transferred by electrophoresis to nitrocellulose membranes. The membranes were blocked with $5 \%$ nonfat dry milk for $1 \mathrm{~h}$ at room temperature and then incubated overnight with antibodies against Caspase- 3 and $\beta$ -actin (Cell Signaling Technology), diluted 1:1,000 with Tris-buffered saline containing $0.05 \%$ Tween 20 (TBS-T). After washing with TBS-T for $1 \mathrm{~h}$, the membranes were incubated for $1 \mathrm{~h}$ at room temperature with horseradish peroxidase-conjugated secondary antibodies diluted 1:2,500 in TBS-T. The membranes were subsequently washed with TBS-T for $1 \mathrm{~h}$, and proteins were detected using Enhanced Chemiluminescence Kit (Santa Cruz Biotechnology, CA, USA). Protein expression was analyzed using Davinch-Chemi ${ }^{\mathrm{TM}}$ Chemiluminescence Imaging System (Davinch-K Co. Ltd., Seoul, Korea). The intensities of bands were measured by densitometry (Imagej program, NIH) and expressed as intensities relative to $\beta$-actin.

\section{Statistical analysis}

The values are expressed as the mean \pm SD. Student's $t$-test was used to examine the differences between control and $O$. japonicus extract-treated samples. $* p<0.05$ and ${ }^{* *} \mathrm{p}<0.01$ were considered as statistically significant.

\section{Results}

\section{Effects of Orostachys japonicus on cell proliferation}

Cholangiocarcinoma SNU-1079 cells were treated with various concentrations of $O$. japonicus DW and EtOH extracts $(0,50,100,200$ and $300 \mu \mathrm{g} / \mathrm{m} \ell)$ for 24,48 or $72 \mathrm{~h}$. The effect of $O$. japonicus on cell proliferation was measured by PMS/MTS colorimetric assay. DW extracts of O. japonicus significantly inhibited the proliferation of SNU-1079 cells in a dose- and time-dependent manner (Fig. 1(A)). The $72 \mathrm{~h}$ EtOH extracts significantly inhibited cell proliferation in a dose-dependent manner (Fig. 1(B)).

\section{Effects of Orostachys japonicus on the apoptosis rate using ELISA assay}

Cholangiocarcinoma SNU-1079 cells were treated with various concentrations of $O$. japonicus DW and $\mathrm{EtOH}$ extracts $(0,100,200$ and $300 \mu \mathrm{g} / \mathrm{m} \ell)$ for 24,48 or $72 \mathrm{~h}$. Apoptotic cells were detected by cell death detection ELISA. Both DW and EtOH extracts increased the number of apoptotic cells at all concentrations (100, 200 and $300 \mu \mathrm{g} / \mathrm{ml})$ and times (24, 48 and $72 \mathrm{~h}$ ), and almost all of the data were statistically significant (Fig. 2(A) and (B)). However, neither dose-dependent nor time-dependent variances were found (Fig. 2(A) and (B)).

\section{Effects of Orostachys japonicus on the apoptosis rate using FACS analysis}

Cholangiocarcinoma SNU-1079 cells were treated with various concentrations (0, 150 and $300 \mu \mathrm{g} / \mathrm{m} \ell)$ of O. japonicus DW and EtOH extracts for 24, 48 
(A)

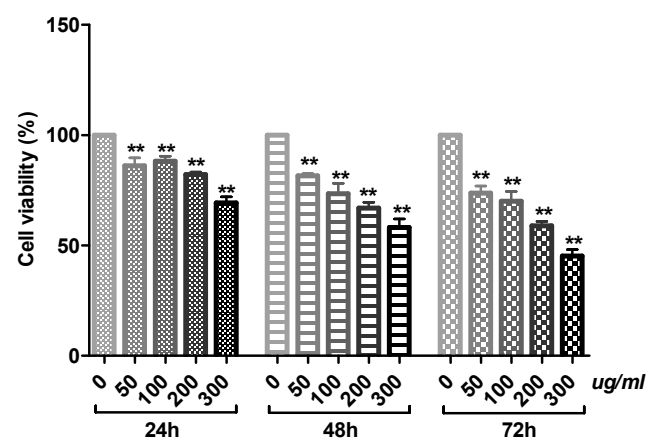

(B) O. japonicus EtOH extracts

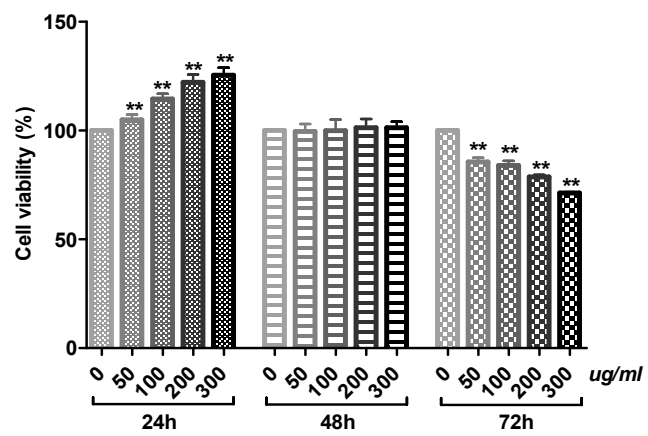

Fig. 1. Cell viability assay

Cells were treated with various concentrations of $\mathrm{O}$. japonicus DW and EtOH extract $(0,50,100,200$ and $300 \mu \mathrm{g} / \mathrm{ml}) \mathrm{for} 24,48$ or $72 \mathrm{~h}$. 0 . japonicus DW extracts inhibited the proliferation of SNU-1079 cells in a dose- and time-dependent manner (A), while EtOH extracts caused inhibition in a dose-dependent manner when cells were treated for $72 \mathrm{~h}$ (B). The data are shown as means \pm SD of samples. ${ }^{*} \mathrm{p}<0.05$ and ${ }^{* *} p<0.01$ compared to control.

(A)

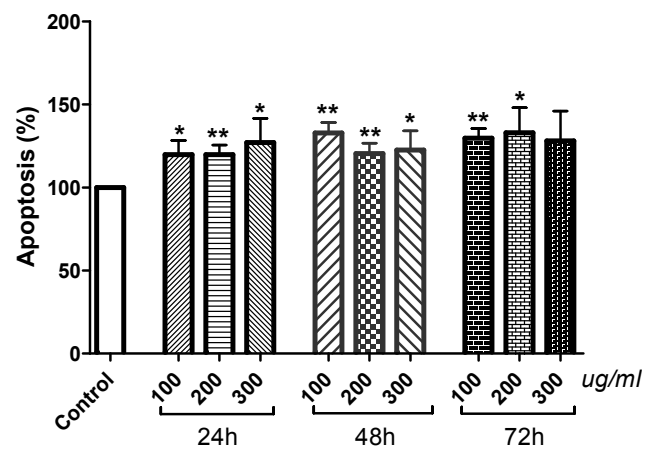

(B) O. japonicus EtOH extracts

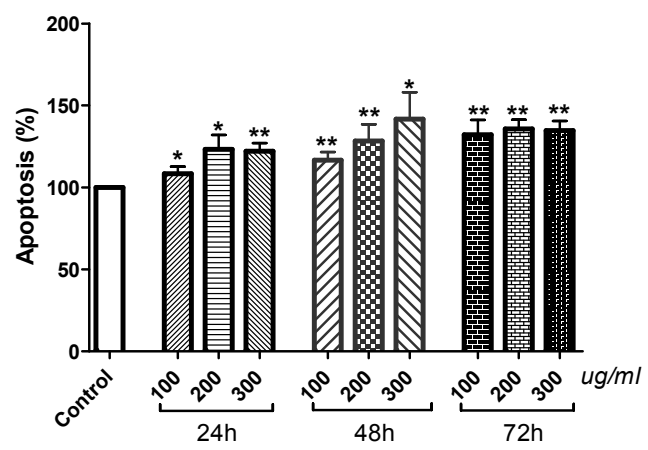

Fig. 2. ELISA assay

Cells were treated with various concentrations of $O$. japonicus DW and EtOH extracts $(0,100,200$ and $300 \mu \mathrm{g} / \mathrm{ml})$ for 24,48 or $72 \mathrm{~h}$. Apoptotic cells were detected using an ELISA assay. Both $O$. japonicus DW and EtOH extracts increased apoptosis rates significantly (A and B). The data are shown as means \pm SD of samples. ${ }^{*} p<0.05$ and ${ }^{* *} p<0.01$ compared to control.

or $72 \mathrm{~h}$, and then analyzed using flow cytometry.

The cells that were undergoing early apoptosis were $\mathrm{FITC}^{+} \mathrm{PI}^{-}$, appearing in the lower right quadrant, while cells undergoing necrosis or late apoptosis were FITC $^{+} \mathrm{PI}^{+}$, appearing in the upper right quadrant. The sum of the cells in both areas, was considered as the total number of apoptotic cells.

The results indicated an increased apoptosis rate with 48 and $72 \mathrm{~h}$ treatment using either DW or EtOH extracts (Fig. 3). There was a dose-dependent increase in apoptotic cells with $72 \mathrm{~h}$ DW extract treatment (Fig. 4(A)) and with 48 and $72 \mathrm{~h} \mathrm{EtOH}$ extract treatments (Fig. 4(B)). The highest apoptosis rate occurred with $300 \mu \mathrm{g} / \mathrm{ml} \mathrm{DW}$ extract treatment for 72 h (Fig. 4(A)). However, with both DW and EtOH extracts, the effect on apoptosis was not notable at $24 \mathrm{~h}$ (Fig. 3 and 4). 
Control
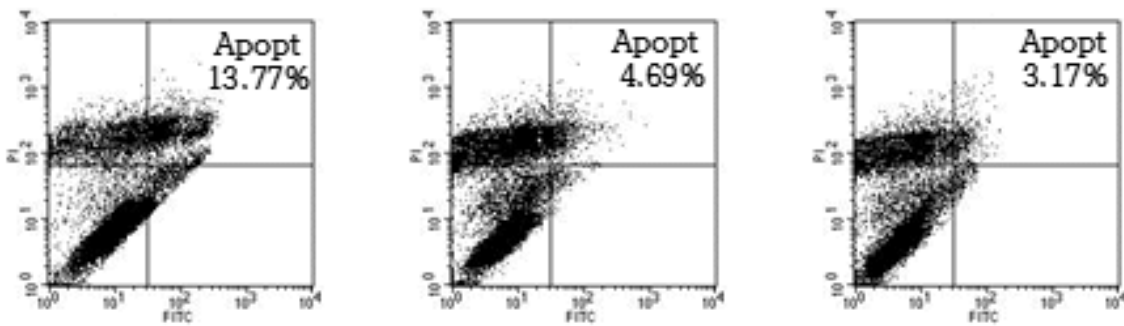

DW extract

$150 \mathrm{\mu g} / \mathrm{ml}$
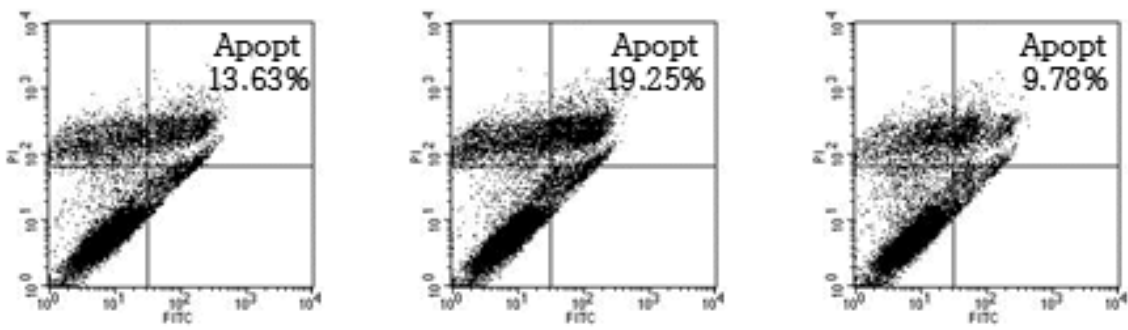

DW extract

$300 \mu \mathrm{g} / \mathrm{ml}$
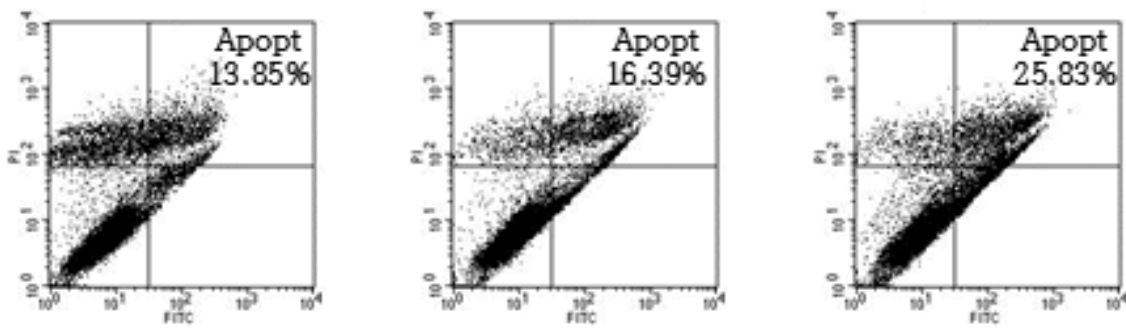

EtOH extract

$150 \mu \mathrm{g} / \mathrm{ml}$
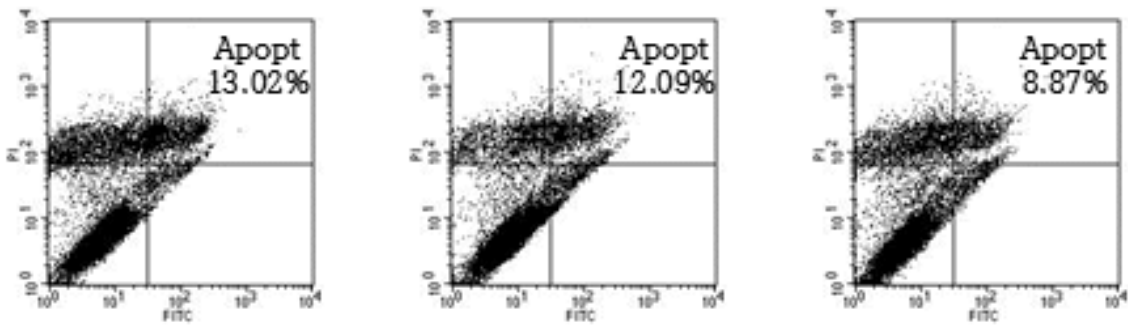

EtOH extract $300 \mu \mathrm{g} / \mathrm{ml}$
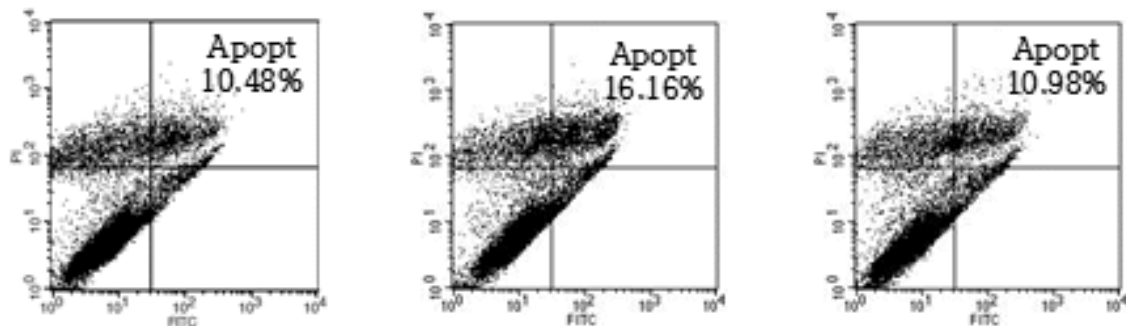

Fig. 3. Apoptosis assay FACS histograms (Annexin V-FITC/PI staining method)

The apoptosis rate was analyzed using flow cytometry. Treatment with 0 . japonicus DW and EtOH extracts for 48 or $72 \mathrm{~h}$ increased the apoptosis rate. 


\section{Effects of Orostachys japonicus on the mRNA expression of apoptosis related genes}

Cholangiocarcinoma SNU-1079 cells were treated with various concentrations of $O$. japonicus DW and $\mathrm{EtOH}$ extracts $(0,150$ and $300 \mu \mathrm{g} / \mathrm{m} \ell)$ for 24 , 48 or $72 \mathrm{~h}$. The mRNA levels of apoptosis- and cell cycle progression-related genes ( $\mathrm{Bcl}-2, \mathrm{Mcl}-1$, Bax, Survivin, Cyclin D1 and p21) were evaluated using real-time PCR to investigate the anti-tumor effect of $O$. japonicus at the level of gene expression.

O. japonicus DW and EtOH extracts decreased Bcl-2, Mcl-1, Survivin, and Cyclin D1 mRNA levels, with some statistically significant changes observed (Fig. 5, 6, 8, and 9). DW extracts significantly increased $B a x$ mRNA levels at particular treatment concentrations and times (Fig. 7(A)), while EtOH extracts did not produce significant increases in Bax mRNA (Fig. 7(B)). There was no clear correlation between treatment time or concentration with p21 mRNA levels for both DW and EtOH extract treatments (Fig. 10), although treatment with $300 \mu \mathrm{g} / \mathrm{m} \ell$ EtOH extract for $24 \mathrm{~h}$ increased p21 mRNA levels significantly (Fig. 10(B)). Overall, treatment with DW extract was more effective than with EtOH extract.

1) $B c l-2$

Both DW and EtOH extracts decreased the $\mathrm{Bcl}-2$ mRNA expression in a dose-dependent manner. For both DW and EtOH extracts, treatment at $300 \mu \mathrm{g} / \mathrm{ml}$ for 24 or $72 \mathrm{~h}$, as well as at $150 \mu \mathrm{g} / \mathrm{ml}$ for $72 \mathrm{~h}$, significantly decreased $\mathrm{Bcl}-2$ mRNA levels (Fig. 5).

\section{2) $M c l-1$}

Mcl-1 mRNA levels decreased in a dose-dependent manner with 24 or $72 \mathrm{~h} \mathrm{DW}$ extract treatment (Fig. 6(A)), as well as with 24 or $48 \mathrm{~h} \mathrm{EtOH}$ extract treatment (Fig. 6(B)). Treatment with DW extract at doses of $150 \mu \mathrm{g} / \mathrm{m} \ell$ and $300 \mu \mathrm{g} / \mathrm{m} \ell$ for 24 and $72 \mathrm{~h}$ (Fig. 6(A)), as well as with EtOH extract at a dose of $300 \mu \mathrm{g} / \mathrm{ml}$ for $24 \mathrm{~h}$ (Fig. 6(B)) significantly reduced mRNA expression.

3) $\operatorname{Bax}$

Treatment with DW extract for $48 \mathrm{~h}$ increased Bax mRNA expression in a dose-dependent manner (Fig. 7(A)). Treatment with DW extract at a dose of $300 \mu \mathrm{g} / \mathrm{ml}$ for $48 \mathrm{~h}$ or $150 \mu \mathrm{g} / \mathrm{ml}$ for $72 \mathrm{~h}$ significantly increased $\operatorname{Bax}$ mRNA levels (Fig. 7(A)). There was no significant increase in $B a x$ mRNA with EtOH extract treatment (Fig. 7(B)).

\section{4) Survivin}

Both DW and EtOH extracts decreased Survivin mRNA levels in a dose-dependent manner for all treatment times. Particularly, for both DW and EtOH extracts, treatment with a $300 \mu \mathrm{g} / \mathrm{m} \ell$ dose, for 24, 48 or 72 h significantly reduced Survivin mRNA expression (Fig. 8).

5) Cyclin D1

DW extracts decreased Cyclin DI mRNA levels in a dose-dependent manner. Treatment with DW extract at a dose of $300 \mu \mathrm{g} / \mathrm{ml}$ for 24,48 or $72 \mathrm{~h}$, as well as at $150 \mu \mathrm{g} / \mathrm{m} l$ for $24 \mathrm{~h}$, significantly reduced mRNA expression (Fig. 9(A)). Treatment with EtOH extract at a dose of $300 \mu \mathrm{g} / \mathrm{m} \ell$ for $24 \mathrm{~h}$ or at $150 \mu \mathrm{g} / \mathrm{ml}$ for $72 \mathrm{~h}$ also significantly decreased Cyclin D1 mRNA levels (Fig. 9(B)). DW extracts were more effective than $\mathrm{EtOH}$ extracts.

6) $p 21$

P21 mRNA expression was not notably increased with either DW or EtOH extract treatment (Fig. 10). Treatment with EtOH extract at a dose of 300 $\mu \mathrm{g} / \mathrm{m} \ell$ for $24 \mathrm{~h}$ (Fig. 10(B)), as well as with DW extract at a dose of $300 \mu \mathrm{g} / \mathrm{ml}$ for $48 \mathrm{~h}$ (Fig. 10(A)) increased p21 mRNA levels, but only the $\mathrm{EtOH}$ extract produced a statistically significant induction. 
(A) Flow cytometry - DW extracts

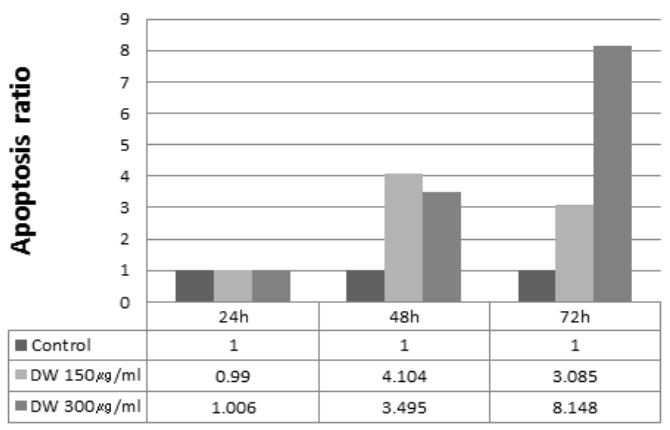

(B) Flow cytometry - EtOH extracts

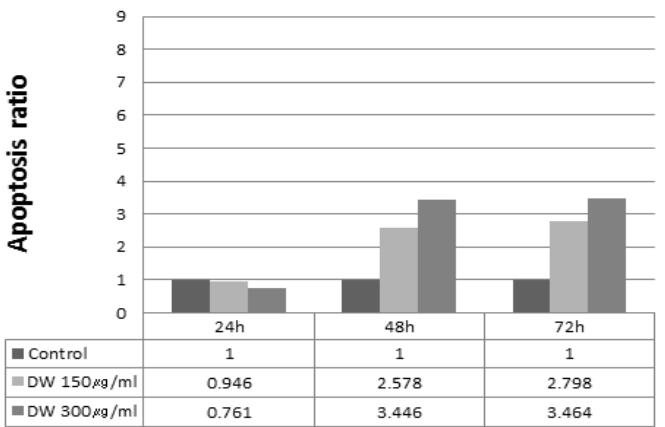

Fig. 4. Apoptosis ratio measured using flow cytometry

Subsequent to flow cytometry apoptosis rate analysis, the apoptosis ratios were calculated in relation to the control samples. Treatment with $O$. japonicus DW extract for $72 \mathrm{~h}$ (A) and EtOH extracts for 48 and $72 \mathrm{~h}$ (B) increased the apoptosis ratio in a dose-dependent manner. Treatment with DW extract at a concentration of $300 \mu \mathrm{g} / \mathrm{ml}$ for $72 \mathrm{~h}$ yielded the highest apoptosis ratio (A).

(A)

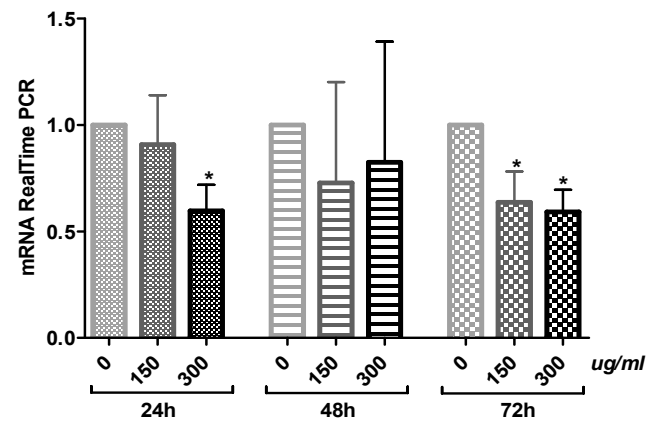

(B) Bcl-2 (EtOH extracts)

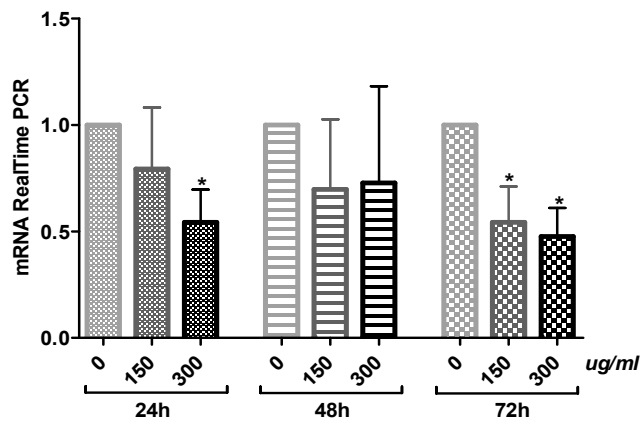

Fig. 5. Bc/-2 mRNA expression

0 . japonicus DW and EtOH extracts decreased $B C /-2$ mRNA levels ( $A$ and $B$ ). The crossing points of $B C /-2$ with $\beta$-actin were applied to the formula $2^{- \text {(target gene }-B \text {-actin) }}$ and the relative amounts of the PCR products were quantified. The data are shown as means $\pm S D$ of samples. ${ }^{*} p<$ 0.05 and ${ }^{* *} p<0.01$ compared to control.

(A)

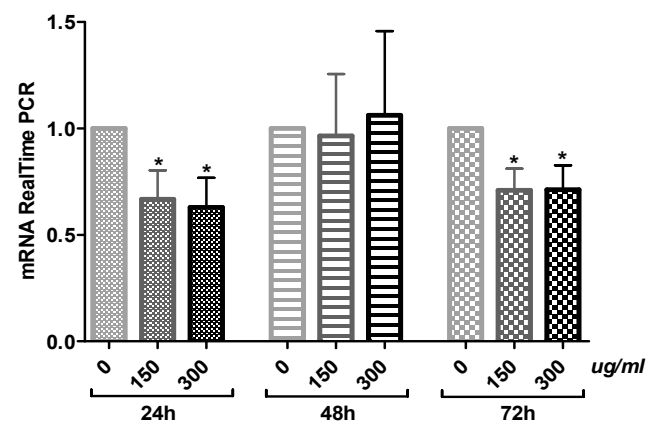

(B) Mcl-1 (EtOH extracts)

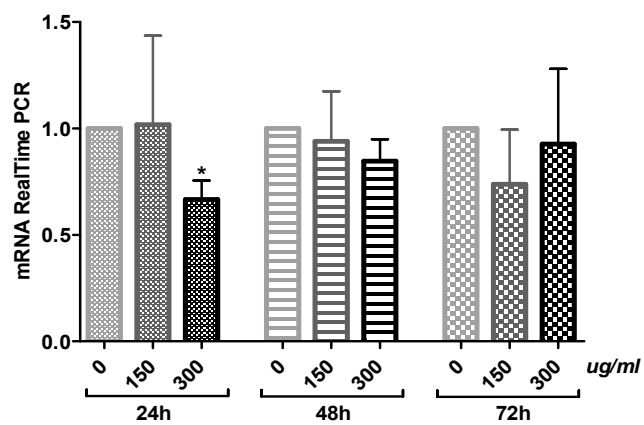

Fig. 6. Mcl-1 mRNA expression

0 . japonicus DW and EtOH extracts decreased Mcl-1 mRNA levels (A and B). Particularly, DW extracts treatment for 24 or $72 \mathrm{~h}$ caused significant reductions (A). The crossing points of $M C l-1$ with $\beta$-actin were applied to the formula $2^{- \text {(target gene }-\beta \text {-actin) }}$ and the relative amounts of the PCR products were quantified. The data are shown as means $\pm S D$ of samples. ${ }^{*} p<0.05$ and ${ }^{* *} p<0.01$ compared to control. 
(A)

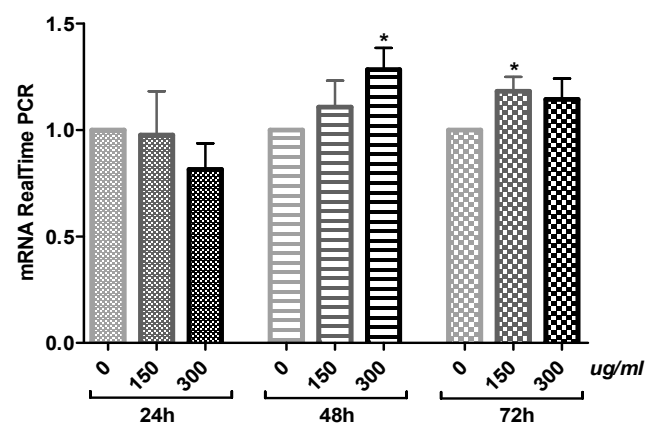

(B)

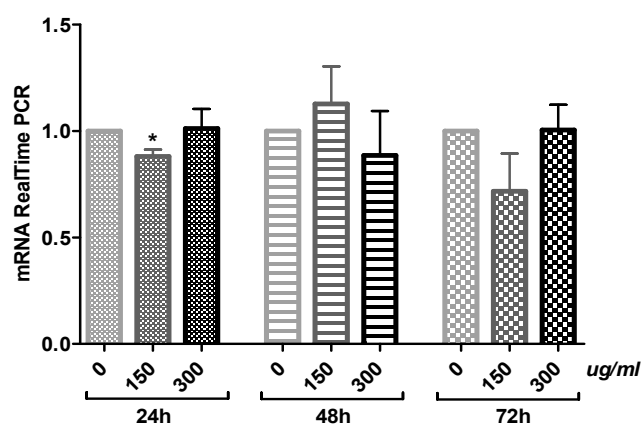

Fig. 7. Bax mRNA expression

O. japonicus DW extracts increased Bax levels in cells treated for 48 and $72 \mathrm{~h}(\mathrm{~A})$. The EtOH extract gave no notable results (B). The crossing points of Bax with $\beta$-actin were applied to the formula $2^{\text {-(target gene - B-actin) }}$ and the relative amounts of the PCR products were quantified. The data are shown as means \pm SD of samples. ${ }^{*} p<0.05$ and ${ }^{* *} p<0.01$ compared to control.
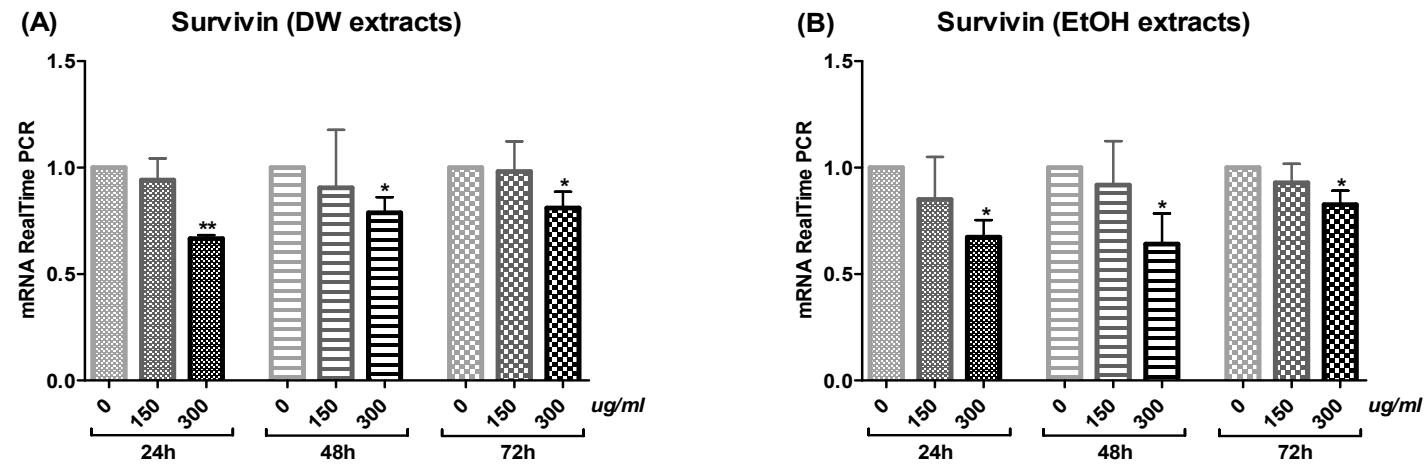

Fig. 8. Survivin mRNA expression

0 . japonicus DW and EtOH extracts decreased Survivin levels. Both DW and EtOH extracts significantly decreased mRNA levels; at a dose of $300 \mu \mathrm{g} / \mathrm{ml}$ at all treatment times, 24,48 , and $72 \mathrm{~h}$ (A and B). The crossing points of Survivin with $\beta$-actin were applied to the formula $2^{\text {-target }}$ gene $-\beta$-actin $)$ and the relative amounts of the PCR products were quantified. The data are shown as means $\pm S D$ of samples. ${ }^{*} p<0.05$ and ${ }^{* *} p$ $<0.01$ compared to control.
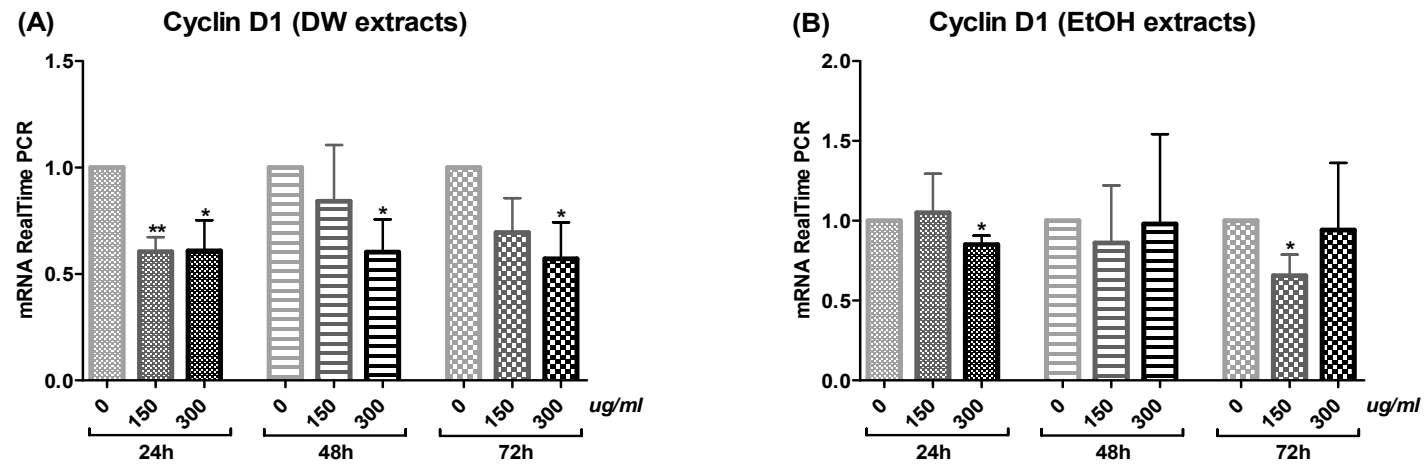

Fig. 9. Cyclin D1 mRNA expression

$O$. japonicus DW and EtOH extracts decreased Cyclin D1 mRNA levels (A and B). DW extracts were more effective than EtOH extracts. The crossing points of Cyclin D1 with $\beta$-actin were applied to the formula $2^{\text {-(target gene }-\beta \text {-actin) }}$ and the relative amounts of the PCR products were quantified. The data are shown as means \pm SD of samples. ${ }^{*} p<0.05$ and ${ }^{* *} p<0.01$ compared to control. 
(A)

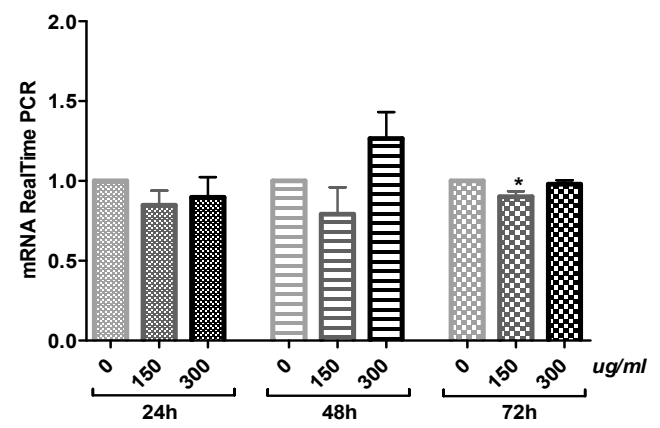

(B)

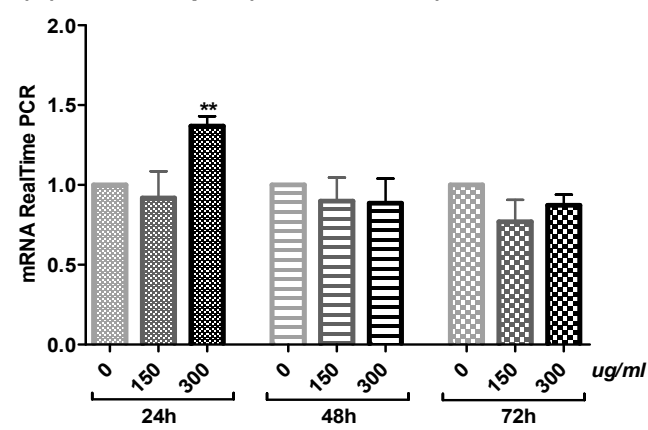

Fig. 10. p21 mRNA expression

Treatment with a $300 \mu \mathrm{g} / \mathrm{ml}$ dose of either DW extract for $48 \mathrm{~h}(\mathrm{~A})$ or EtOH extract for $24 \mathrm{~h}(\mathrm{~B})$, showed an increase in $p 21 \mathrm{mRNA}$ levels. Other doses and treatment times produced no notable results. The crossing points of $p 21$ with $\beta$-actin were applied to the formula $2^{\text {-(target gene }-B \text {-actin) }}$ and the relative amounts of the PCR products were quantified. The data are shown as means \pm SD of samples. ${ }^{*} p<0.05$ and ${ }^{* *} p<0.01$ compared to control.
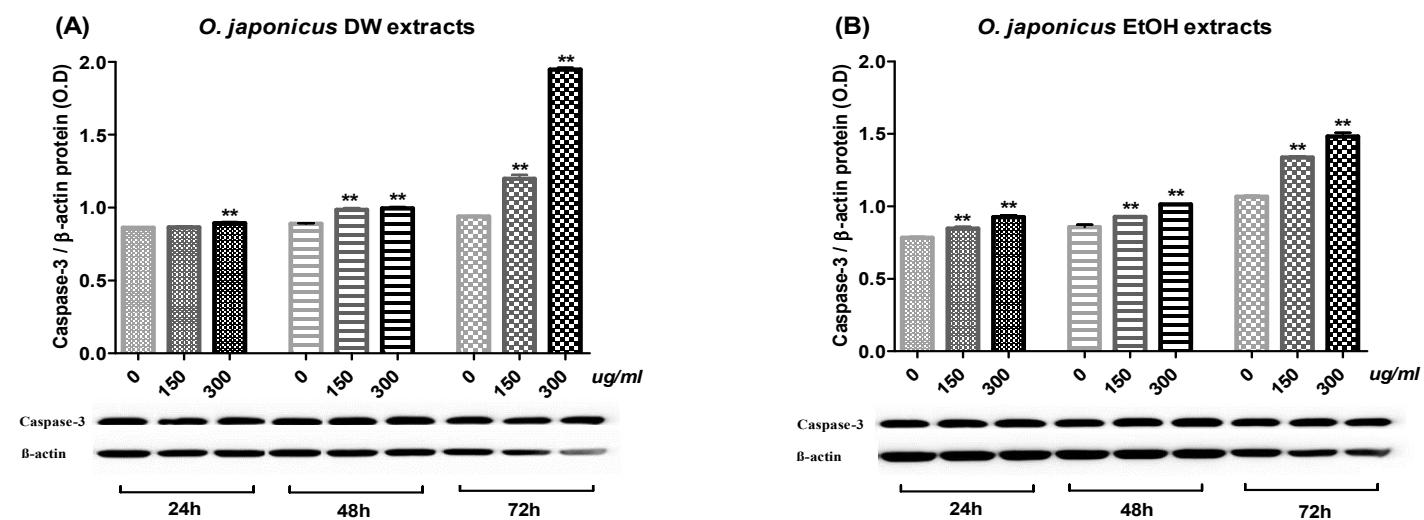

Fig. 11. Caspase-3 / $\beta$-actin protein expression using Immunoblot analysis

O. japonicus DW and EtOH extracts significantly increased Caspase-3 activity in SNU-1079 cells in a dose- and time-dependent manner (A and B). Treatment with DW extract at a concentration of $300 \mu \mathrm{g} / \mathrm{mlfor} 72 \mathrm{~h}$ yielded the highest increase (A). The data are shown as means $\pm S D$ of samples. ${ }^{*} p<0.05$ and ${ }^{* *} p<0.01$ compared to control.

\section{Effects of Orostachys japonicus on Caspase- 3 activation}

Cholangiocarcinoma SNU-1079 cells were treated with various concentrations of $O$. japonicus DW and EtOH extracts $(0,150$ and $300 \mu \mathrm{g} / \mathrm{m} \ell)$ for 24 , 48 or $72 \mathrm{~h}$. To investigate the molecular mechanism of $O$. japonicus-induced apoptosis, changes in the activation of Caspase-3 protein were examined by immunoblot analysis. Densitometric analyses are presented as the relative ratios of Caspase-3 to $\beta$ -actin.

Both DW and EtOH extracts increased Caspase-3 activity in SNU-1079 cells in a dose- and time-dependent manner, and almost all of the data were statistically significant (Fig. 11). Particularly, treatment with DW and EtOH extracts for $72 \mathrm{~h}$ increased Caspase-3 activation prominently (Fig. 11). DW extract at a dose of $300 \mu \mathrm{g} / \mathrm{m} l$ and the treatment time of $72 \mathrm{~h}$ produced the highest induction (Fig. 11(A)). 


\section{Discussion and Conclusion}

Cholangiocarcinoma (CCA) originates from the malignant transformation of cholangiocytes, the epithelial cells lining the biliary ducts 5 . CCA is highly fatal as in most patients the cancer is recognized when it is already locally advanced ${ }^{1}$. Over the past three decades, the overall incidence of CCA appears to have increased, but the percentage of patients who survive more than five years after diagnosis still remains at $10 \%{ }^{35,36}$. An investigation into candidate treatments for intrahepatic CCA (iCCA) seems particularly necessary, as data from the National Cancer Institute Surveillance, Epidemiology and End Results (NCI-SEER) program suggest that approximately $15 \%$ of bile duct cancers are iCCAs ${ }^{10,37}$. Therefore, we utilized an iCCA human biliary tract cell line, SNU-1079, to conduct our study.

Several trials have been made to find potential anti-tumor treatments from a range of Korean medicinal herbs; Orostachys japonicus(O. japonicus) is one of the traditional medicines used as an anti-tumor agent in Korea, which is known to have heat-clearing, dispersing swelling, hemostatic, and dampness-draining effects. In a previous study, $O$. japonicus inhibited growth in the human hepatic stellate cell line LX2, by inducing apoptosis via MAPK pathway regulated Caspase activation ${ }^{27}$. Furthermore, other studies have reported that $O$. japonicus induced apoptosis in human acute promyelocytic leukemia HL60 cells $^{29}$ and chronic myeloid leukemia $\mathrm{K} 562 \mathrm{cells}^{28}$, apoptosis and sub-G1 phase cell cycle arrest in human colon cancer SW480 cells ${ }^{30}$, and cell death in human prostate cancer RC-58T/h/SA\#4 cells ${ }^{31}$. Consequently, we considered $O$. japonicus as a promising therapeutic against cholangiocarcinoma and further investigated its anti-tumor effects. The process of apoptosis is essential in regulating the homeostasis of the biliary epithelium as it permits the removal of severely damaged cells with non-reversible genomic mutations ${ }^{38}$. Hence, this study reports the capability of $O$. japonicus to induce apoptosis.

To evaluate the effect of $O$. japonicus treatment on cell viability, a PMS/MTS assay was performed. O. japonicus DW extracts inhibited SNU-1079 cell proliferation in a dose-and time-dependent manner (Fig. 1(A)), whereas EtOH extracts inhibited proliferation in a dose-dependent manner but only at $72 \mathrm{~h}$ (Fig. 1(B)); this might be related to the doubling time of SNU-1079 cells, which is known to be $72 \mathrm{~h}$. Considering that Korean traditional herbal medicines are usually administered in the form of DW extract, the result suggests that the traditional decoction method is effective for $O$. japonicus administration. A similar trend also appeared in following experiments.

We investigated the apoptosis rate of SNU-1079 cells with $O$. japonicus extract treatment, with the reasoning that a defect in the apoptotic process leads to the survival of mutated cholangiocytes, which can undergo a series of other mutations resulting in the malignant transformation of the cells $^{38}$. ELISA assay and FACS analysis were performed to measure the apoptosis rate. Results from the ELISA assay showed that, $O$. japonicus significantly increased the apoptosis rate at almost all concentrations and treatment times, but dose- or time-dependent differences were not seen (Fig. 2). This result suggests that both $O$. japonicus DW and $\mathrm{EtOH}$ extracts at doses over $100 \mu \mathrm{g} / \mathrm{ml}$ and treatment times over $24 \mathrm{~h}$ long can induce the apoptosis of SNU-1079 cholangiocarcinoma cells. Flow cytometric analysis also showed increased apoptosis rates with $O$. japonicus extract treatments. The sum of the dead or necrotic cells and cells in apoptosis, was considered as the total number of apoptotic cells. The results suggest that $O$. japonicus DW and EtOH extracts induce apoptosis in SNU-1079 cells when treated with $150 \mu \mathrm{g} / \mathrm{m} \ell$ and $300 \mu \mathrm{g} / \mathrm{ml}$ doses for 48 or $72 \mathrm{~h}$ (Fig. 3 and 4). 
Overall, DW extracts were more effective than EtOH extracts, and treatment with DW extract at a dose of $300 \mu \mathrm{g} / \mathrm{m} \ell$ for $72 \mathrm{~h}$ produced the highest apoptosis rate, 25.83\% (Fig. 3 and 4(A)). Unlike with the ELISA assay, by FACS analysis $O$. japonicus DW and EtOH extracts were revealed to be ineffective for $24 \mathrm{~h}$ long treatments (Fig. 3 and 4).

To demonstrate the anti-tumor effect of $O$. japonicus at the gene expression level, we examined the changes in the mRNA expression of apoptosis-related genes in $O$. japonicus extract treated SNU-1079 cells. Results showed that, $O$. japonicus DW and EtOH extracts reduced the expression of anti-apoptotic genes $\mathrm{Bcl}-2$ and $\mathrm{Mcl}-\mathrm{I}$ (Fig. 5 and 6). The Bcl-2 superfamily of anti-apoptotic proteins is expressed in CCA cells in a high amounts. In CCA cells, Bcl-2 protein exerts its anti-apoptotic activity by preventing cytochrome-c release from the mitochondria thus reducing Caspase-3 activation ${ }^{39}$. Myeloid cell leukemia-1 (Mcl-1) belongs to the Bcl-2 family, and increases cancer cell resistance to tumor-necrosis-factor (TNF) related apoptosis-inducing ligand (TRAIL) ${ }^{40}$. The expression of Mcl-1 is also stimulated by bile acids, abundant in the course of cholestasis ${ }^{41}$. In that, Mcl-1 appears to have an important role in the development of $\mathrm{CCA}^{42}$. Therefore, it is noteworthy that $O$. japonicus $\mathrm{DW}$ extracts significantly decreased mRNA levels of both of these genes in a dose-dependent manner with 24 or $72 \mathrm{~h}$ treatment (Fig. 5(A) and 6(A)). Pro-apoptotic protein Bax is believed to induce the opening of the mitochondrial voltage-dependent anion channel (VDAC), thereby releasing cytochrome $\mathrm{c}$ and other pro-apoptotic factors from the mitochondria ${ }^{43}$. Cells treated with O. japonicus DW extracts at a concentration of 150 $\mu \mathrm{g} / \mathrm{m} \ell$ or $300 \mu \mathrm{g} / \mathrm{ml}$ for 48 or $72 \mathrm{~h}$ exhibited increased Bax mRNA levels (Fig. 7(A)). However, EtOH extracts did not produce notable effects on Bax mRNA expression (Fig. 7(B)). Since Bcl-2 and
Bax genes regulate apoptosis through the intrinsic pathway, which is characterized by the permeabilization of the mitochondria and release of cytochrome $\mathrm{c}$ into the cytoplasm ${ }^{44}$, the data suggest that O. japonicus extracts induce SNU-1079 cell apoptosis via the mitochondria-mediated intrinsic pathway by regulating $\mathrm{Bcl}-2$ and $\mathrm{Bax}$ expression. Moreover, DW extract seems more effective than EtOH extract.

We also investigated the mRNA expression of cell cycle progression related genes. Survivin is one of the inhibitor of apoptosis (IAP) family proteins, and functions to inhibit caspase activation, thus leading to inhibition of apoptosis or programmed cell death ${ }^{45}$. Its expression is also highly regulated by the cell cycle as it is only expressed in the G2-M phase. Cyclin D1 is a protein required for cell progression through the G1 phase of the cell cycle $^{46}$. It is synthesized rapidly during the G1 phase and accumulates in the nucleus. It is degraded as the cell enters the $\mathrm{S}$ phase. Overexpression of Cyclin D1 has been shown to correlate with early cancer onset and tumor progression, which can lead to oncogenesis through angiogenesis brought about by increased VEGF production ${ }^{47,48}$. In this study, $O$. japonicus DW extracts decreased Survivin and Cyclin D1 mRNA levels in a dose-dependent manner. DW extract at a $300 \mu \mathrm{g} / \mathrm{m} \ell$ dose significantly inhibited both Survivin and Cyclin D1 mRNA expression for all treatment times, 24, 48 and $72 \mathrm{~h}$ (Fig. 8(A) and 9(A)). Similar to DW extracts, EtOH extracts also significantly decreased Survivin mRNA levels in a dose-dependent manner, in cells treated with $300 \mu \mathrm{g} / \mathrm{ml}$ of extract for 24,48 or $72 \mathrm{~h}$ (Fig. 8(B)), whereas the effect on Cyclin D1 expression was not dose-dependent (Fig. 9(B)). P21 (CIP1/WAF1) is a potent cyclin-dependent kinase inhibitor (CKI). This protein inhibits the activity of cyclin-CDK2, -CDK1, and -CDK4/6 complexes, thus it functions as a regulator of cell cycle progression at the $\mathrm{G} 1$ and $\mathrm{S}$ phase ${ }^{49}$. We expected 
O. japonicus to increase $p 21$ mRNA levels, but the results generally did not show this tendency (Fig. 10). The mRNA levels of this gene only increased when SNU-1079 cells were treated with $300 \mu \mathrm{g} / \mathrm{m} \ell$ of DW extract for $48 \mathrm{~h}$ (Fig. 10(A)) or $300 \mu \mathrm{g} / \mathrm{m} \ell$ of EtOH extract for $24 \mathrm{~h}$ (Fig. 10(B)). These results indicate that, $O$. japonicus regulates cell cycle progression by regulating Survivin and Cyclin DI mRNA expression levels, but its association with p21 is not understood completely. Regarding the known fact that Survivin is only expressed in the G2-M phase, and Cyclin D1 is required for progression through the G1 phase of the cell cycle, we can assume that the effect of $O$. japonicus might function by regulating the G1-G2-M phases of cell cycle progression. Further studies are needed to confirm this hypothesis.

To find out molecular pathway of apoptosis, we evaluated Caspase-3 activation in SNU-1079 cells with $O$. japonicus extract treatments using immunoblot analysis. Apoptosis can be initiated by three different pathways in mammals: the extrinsic pathway, the intrinsic pathway, or the granzyme B pathway $^{50}$. Caspase-3 is the main executioner protein in apoptotic cells as it can be activated through both extrinsic and intrinsic signaling pathway $^{51}$. In immunoblot analysis, O. japonicus DW and EtOH extracts significantly increased Caspase-3 activation in a dose- and time-dependent manner (Fig. 11). The result suggests that $O$. japonicus extracts induce caspase-dependent apoptosis by regulating pro- or anti-apoptotic genes, which can lead to increase of Caspase-3 activation.

In conclusion, $O$. japonicus decreased cell viability, increased apoptosis rate in both ELISA assay and flow cytometry analysis, and regulated mRNA expression of apoptosis-related genes $B c l-2$, Mcl-1, Bax, Survivin, and Cyclin D1. The effect on the p21 gene is uncertain. O. japonicus also increased Caspase-3 protein activation. DW extracts produced more significant effects than $\mathrm{EtOH}$ extracts in the cell viability assay, FACS analysis, and real-time PCR analysis. Particularly, treatment with DW extract at $300 \mu \mathrm{g} / \mathrm{ml}$ dose for $72 \mathrm{~h}$ produced the most significant effects. These results taken together, indicate that $O$. japonicus DW and EtOH extracts show anti-tumor effects on SNU-1079 cells through inhibition of cell proliferation and induction of apoptosis via the mitochondria -mediated intrinsic pathway which leads to Caspase-3 activation. Since SNU-1079 is iCCA cell line, $O$. japonicus is revealed to be a possible therapeutic herbal medicine for iCCA. Further investigations are required to define the molecular mechanisms through which $O$. japonicus induces apoptosis, via the extrinsic pathway and the granzyme B pathway. Investigation to confirm the hypothesis that $O$. japonicus functions by regulating G1-G2-M cell cycle progression, also needed.

\section{References}

1. Rizvi S, Gores GJ. Pathogenesis, diagnosis, and management of cholangiocarcinoma. Gastroenterology. 2013;145:1215-29.

2. Shaib Y, El-Serag H.B. The epidemiology of cholangiocarcinoma. Seminars in liver disease 2004(24)115-25.

3. Welzel TM, McGlynn KA, Hsing AW, O'Brien TR., Pfeiffer RM. Impact of classification of hilar cholangiocarcinomas (Klatskin tumors) on the incidence of intra- and extrahepatic cholangiocarcinoma in the United States. Journal of the National Cancer Institute. 2006; 98:873-5.

4. Fava G, Lorenzini I. Molecular pathogenesis of cholangiocarcinoma. Int J Hepatol. 2012;2012: 1-7.

5. Lazaridis $\mathrm{KN}$, Gores GJ. Cholangiocarcinoma. Gastroenterology. 2005;128:1655-67.

6. Sripa B, Pairojkul C. Cholangiocarcinoma: lessons from Thailand. Current opinion in 
gastroenterology. 2008;24:349-56.

7. Khan SA, Taylor-Robinson SD, Toledano M.B, Beck A, Elliott P, Thomas HC. Changing international trends in mortality rates for liver, biliary and pancreatic tumours. Journal of hepatology. 2002;37:806-13.

8. Khan SA., Toledano MB, Taylor-Robinson SD. Epidemiology, risk factors, and pathogenesis of cholangiocarcinoma. HPB : the official journal of the International Hepato Pancreato Biliary Association. 2008;10:77-82.

9. McGlynn KA, Tarone RE, El-Serag HB. A comparison of trends in the incidence of hepatocellular carcinoma and intrahepatic cholangiocarcinoma in the United States. Cancer epidemiology, biomarkers \& prevention $\therefore$ a publication of the American Association for Cancer Research, cosponsored by the American Society of Preventive Oncology. 2006;15: 1198-203.

10. Patel, T. Increasing incidence and mortality of primary intrahepatic cholangiocarcinoma in the United States. Hepatology. 2001;33:1353-7.

11. Fava G, Marzioni M, Benedetti A, Glaser S, DeMorrow S, Francis $\mathrm{H}$, et al. Molecular pathology of biliary tract cancers. Cancer letters. 2007;250:155-67.

12. Sandhu DS, Shire AM, Roberts LR. Epigenetic DNA hypermethylation in cholangiocarcinoma: potential roles in pathogenesis, diagnosis and identification of treatment targets. Liver international : official journal of the International Association for the Study of the Liver. 2008; 28:12-27.

13. Tischoff I, Wittekind C, Tannapfel A. Role of epigenetic alterations in cholangiocarcinoma. Journal of hepato-biliary-pancreatic surgery. 2006;13:274-9.

14. Lowe SW, Lin AW. Apoptosis in cancer. Carcinogenesis. 2000;21:485-95.

15. Thompson CB, Apoptosis in the pathogenesis and treatment of disease. Science. 1995;267: 1456-62.

16. Danial NN, Korsmeyer SJ. Cell death: critical control points. Cell. 2004;116:205-19.

17. Taylor RC, Cullen SP, Martin SJ. Apoptosis: controlled demolition at the cellular level. Nature reviews. Molecular cell biology. 2008; 9: 231-41.

18. Tsuruo T, Naito M, Tomida A, Fujita, N, Mashima T, Sakamoto $\mathrm{H}$, et al. Molecular targeting therapy of cancer: drug resistance, apoptosis and survival signal. Cancer science. 2003;94:15-21.

19. Debatin KM, Apoptosis pathways in cancer and cancer therapy. Cancer immunology, immunotherapy:CII. 2004;53:153-9.

20. Lee HS, Ryu DS, Lee GS, Lee DS. Anti-inflammatory effects of dichloromethane fraction from Orostachys japonicus in RAW 264.7 cells: suppression of NF-kappaB activation and MAPK signaling. Journal of ethnopharmacology. 2012;140:271-6.

21. Yoon Y, Kim KS, Hong SG, Kang BJ, Lee M Y, Cho DW. Protective effects of Orostachys japonicus A. Berger (Crassulaceae) on H2O2-induced apoptosis in GT1-1 mouse hypothalamic neuronal cell line. Journal of ethnopharmacology. 2000;69:73-8.

22. Jung HJ, Choi J, Nam JH, Park HJ. Anti-ulcerogenic effects of the flavonoid-rich fraction from the extract of Orostachys japonicus in mice. Journal of medicinal food. 2007; 10:702-6.

23. Park JC, Han WD, Park JR, Choi SH, Choi J W. Changes in hepatic drug metabolizing enzymes and lipid peroxidation by methanol extract and major compound of Orostachys japonicus. Journal of ethnopharmacology. 2005; 102:313-8.

24. Shin DY, Lee WS, Jung JH, Hong SH, Park C, Kim HJ, et al. Flavonoids from Orostachys 
japonicus A. Berger inhibit the invasion of LnCaP prostate carcinoma cells by inactivating Akt and modulating tight junctions. International journal of molecular sciences. 2013;14:18407-20.

25. Ryu DS, Kim SH, Kwon JH, Lee DS. Orostachys japonicus induces apoptosis and cell cycle arrest through the mitochondria -dependent apoptotic pathway in AGS human gastric cancer cells. International journal of oncology. 2014;45:459-69.

26. Lee WS, Yun JW, Nagappan A, Jung JH, Yi SM, Kim DH et al. Flavonoids from Orostachys japonicus A. Berger induces caspase-dependent apoptosis at least partly through activation of p38 MAPK pathway in U937 human leukemic cells. Asian Pacific journal of cancer prevention : APJCP. 2015; 16:465-9.

27. Kim YI, Park SW, Choi IH, Lee JH, Woo HJ, Kim, Y. Effect of Orostachys japonicus on cell growth and apoptosis in human hepatic stellate cell line LX2. The American journal of Chinese medicine. 2011;39:601-13.

28. Yun KS, Lee JH, Woo Hj. Effect of Orostachys japonicus A. berger in Apoptosis in K562 Cell Lines. Korean J. Orient. Int. Med. 2006;27: 166-177.

29. Oh $\mathrm{CH}$, Kim NS, Jeon HJ, Han KS, Lee MJ Lee, Kwon J. Effect of Orostachys japonicus A. Berger on Apoptosis Induction of Human Leukemia HL60 Cells. Kor. J. Pharmacogn. 2009;40:118-122.

30. Kim JY, Won YS, Lee JH, Shin DY, Seo KI. Cultivated Orostachys japonicus Induces Apoptosis in Human Colon Cancer Cells. KOREAN J. FOOD SCI. TECHNOL. 2012;44: 317-323.

31. Won YS, Kwon SJ, Ahn DU, Shin DY, Seo KI. Anticancer Effects of Cultivated Orostachys japonicus on Human Prostate Cancer Cells. $J$ Korean Soc Food Sci Nutr. 2014;43:67-73.

32. $\mathrm{Ku} \mathrm{JL}$, Yoon KA, Kim IJ, Kim WH, Jang
JY, Suh KS, et al. Establishment and characterisation of six human biliary tract cancer cell lines. British journal of cancer. 2002;87:187-93.

33. Joung B, Kim Y. Study on Anti-Cancer Effects of Rhus Verniciflua Stokes Extracted with Sterile Distilled Water on Two Cholangiocarcinoma Cell Lines, SNU-1079 and SNU-1196. J. Int. Korean Med. 2015;36:1-12.

34. Park JK. Pro-apoptotic Effects of Sanguisorbae Radix Ethanol-Extracts on Two Cholangiocarcinoma Cell Lines, SNU-1079 and SNU-1196. Korean J. Orient. Int. Med. 2012;33:465-475.

35. Khan SA, Davidson BR, Goldin RD, Heaton N, Karani J, Pereira SP. Guidelines for the diagnosis and treatment of cholangiocarcinoma: an update. Gut. 2012;61:1657-69.

36. Tyson GL, El-Serag HB, Risk factors for cholangiocarcinoma. Hepatology. 2011;54:173-84.

37. Shaib YH, Davila JA., McGlynn K, El-Serag HB. Rising incidence of intrahepatic cholangiocarcinoma in the United States: a true increase? Journal of hepatology. 2004;40:472-7.

38. Alpini G, McGill JM, Larusso NF. The pathobiology of biliary epithelia. Hepatology. 2002;35:1256-68.

39. Harnois DM, Que FG, Celli A, LaRusso N F, Gores GJ. Bcl-2 is overexpressed and alters the threshold for apoptosis in a cholangiocarcinoma cell line. Hepatology. 1997;26:884-90.

40. Taniai M, Grambihler A, Higuchi H, Werneburg N, Bronk SF, Farrugia DJ. et al. Mcl-1 mediates tumor necrosis factor-related apoptosis-inducing ligand resistance in human cholangiocarcinoma cells. Cancer research. 2004;64:3517-24.

41. Rizvi S, Gores GJ. Molecular pathogenesis of cholangiocarcinoma. Digestive diseases. 2014; 32:564-9.

42. Kobayashi S, Werneburg NW, Bronk SF, Kaufmann SH, Gores GJ. Interleukin-6 contributes to Mcl-1 up-regulation and TRAIL 
resistance via an Akt-signaling pathway in cholangiocarcinoma cells. Gastroenterology. 2005; 128:2054-65.

43. Shi Y, Chen J, Weng C, Chen R, Zheng Y, Chen $\mathrm{Q}$, et al. Identification of the protein-protein contact site and interaction mode of human VDAC1 with Bcl-2 family proteins. Biochemical and biophysical research communications. 2003; 305:989-96.

44. Kroemer G, Galluzzi L, Brenner C. Mitochondrial membrane permeabilization in cell death. Physiological reviews. 2007;87: 99-163.

45. Sah NK, Khan Z, Khan GJ, Bisen PS. Structural, functional and therapeutic biology of survivin. Cancer letters. 2006;244:164-71.

46. Baldin V, Lukas J, Marcote MJ, Pagano M, Draetta G. Cyclin D1 is a nuclear protein required for cell cycle progression in G1. Genes \& development. 1993;7:812-21.
47. Diehl JA. Cycling to cancer with cyclin D1. Cancer biology \& therapy. 2002;1:226-31.

48. Shintani M, Okazaki A, Masuda T, Kawada M, Ishizuka M, Doki Y, et al. Overexpression of cyclin DI contributes to malignant properties of esophageal tumor cells by increasing VEGF production and decreasing Fas expression. Anticancer research. 2002;22:639-47.

49. Gartel AL, Radhakrishnan SK. Lost in transcription: p21 repression, mechanisms, and consequences. Cancer research. 2005;65:3980-5.

50. Ghavami S, Hashemi M, Ande SR, Yeganeh B, Xiao W, Eshraghi $\mathrm{M}$, et al. Apoptosis and cancer: mutations within caspase genes. Journal of medical genetics. 2009;46:497-510.

51. Porter AG, Janicke RU. Emerging roles of caspase-3 in apoptosis. Cell death and differentiation. 1999;6:99-104. 